\author{
Галина Полисаєва, \\ викладач кафедри менеджменту \\ освіти і практичної психології \\ ДВНЗ «Переяслав-Хмельницький \\ державний педагогічний \\ університет імені Григорія \\ Сковороди».
}

Halyna Polysaeva, Lecturer of the Department of Management of Education and

Practical Psychology SHEI «Pereiaslav-Khmelnytskyi Hryhorii Skovoroda State Pedagogical University».

\author{
E-mail: $h p . z @ u k r . n e t$ \\ ORCID 0000-0001-8213-6419
}

\title{
ВПЛИВ ДИТЯЧОЇ ЛІТЕРАТУРИ НА РОЗВИТОК ЕМОЦІЙНОГО ІНТЕЛЕКТУ ДОШКІЛЬНИКІВ
}

\begin{abstract}
У статті здійснено теоретичний аналіз впливу художньої літератури на розвиток емоційного інтелекту та творчої уяви дітей дошкільного віку. Виявлено особливості взаємозв'язку казкотерапії та емочійного інтелекту, які розвиваються у дошкільників разом 3 рефлексією та творчим потенціалом. Розглянуто, як за допомогою художньої літератури та здатності дітей до рефлексії відбувається прищеплення поведінкових норм суспільства. Описано дочільність наведення дорослими у спілкуванні з дітьми прикладів власної поведінки в різних життєвих ситуаціях. Обтрунтовано необхідність спонукати дитину до процесу пізнання світу казок та важливість підштовхувати дошкільника до аналізу фантастичних сюжетів, установлення взаємодії персонажів, стимулювання до створення власних оповідань. Проаналізовано різні наукові концепиії щзодо впливу літератури на емоційний інтелект дошкільників. Висвітлено, як систематичне вправляння з дитячою літературою суттєво сприяє створенню нових нейронних сполучень та покращенню мозкової активності дітей дошкільного віку. Виявлено, щзо процес розвитку емоційного інтелекту має свої особливості, проте основні його структурні елементи починають розвиватися в старшому дошкільному віці та вдосконалюються впродовж усього шкільного періоду навчання. Зосереджено увагу на першооснові розвитку емоційного інтелекту як одного із ключових елементів розвитку уяви дочкільників, до яких можна віднести дитячу художню літературу, оповідання, казки та байки. Доведено, щчо розвиток емоиійного потенціалу в дошкільному віч̨і допоможе регулювати власний настрій та поведінку, навчить співпрацювати з дорослими та однолітками, сприятиме вирішенню сочіально важливих питань у майбутньому. Зроблено висновок про те, щзо в основі виховання дітей дошкільного віку є гостра потреба не лише у формуванні знань, а й у розвитку емоційної сфери.
\end{abstract}

Ключові слова: емоційний інтелект, рефлексія, інтроспекція, творчий потенціал, соиіалізація, самосвідомість, саморегуляція, емпатія, казкотерапія, поведінкові настанови.

The article examines the influence of fiction on the development of emotional intelligence and the creative imagination of preschool children. The article considers the close relationship between the fairy tales therapy and the development of emotional intelligence that develops in preschoolers along with reflection and creative potential. Here are considered the implantation of behavioral norms of society using fiction and ability of children to reflect. Also, the article considers the expediency of guiding examples of adult behavior in different life situations. In the article are substantiated the necessity of encouraging the child in the process of knowing the fairy tales world and the importance of inducing the preschooler to the analysis of fantastic plots, establishing relationships of characters interaction, stimulation to create their own stories is substantiated. Different doctrines which are determine the influence of literature on emotional intelligence of preschoolers were analyzed. Systematic actions with children literature substantially have influence on creating new neural pathways and improves mind activity in preschoolers age were enlightened. Find out, that development of emotional potential process have its own features, however, main structure elements develops in elder 
preschooler age and improves along school period. Focused on basics of the development of emotional intelligence as key element of development imagination of preschool children, which are children fiction literature, short tales, fairytales and fables. It is proved that the development of emotional potential in preschool age will help to regulate own mood and behavior, will teach to cooperate with adults and peers, will help to solve socially important issues in future. The inference made that the basic thing of upbringing children contains an urgent need not only in knowledge building, but also in the development of emotional sphere.

Keywords: emotional intelligence, reflection, introspection, creative potential, socialization, self-consciousness, self-regulation, empathy, fairy tale therapy, behavioral mindset.

Постановка проблеми. У контексті сучасності, на етапі розвитку інформаційного суспільства особливо гостро постає питання детермінант формування та розвитку творчого потенціалу кожного індивіда. Кінець 20-го століття визнаний вченими надзвичайно продуктивним на значні відкриття в галузі психології, саме в цей період ученим вдалося більш ретельно дослідити роль емоційного інтелекту в житті кожного індивіду. Напрацювання дослідників у минулому дозволяє визначити емоційний інтелект як здатність до соціальної адаптації, вміння використовувати, розуміти емоції оточуючих. Емоційний інтелект - це інструмент для саморегуляції людини, зменшення стресу, ефективного спілкування, виявлення емпатії до інших людей, можливості відповідати на виклики життя та вирішення конфліктів.

Аналіз останніх досліджень $\boldsymbol{i}$ публікацій. Відповідно до спостережень доктора Дж. Готтмана який в книзі «Емоційний інтелект дитини. Практичний посібник для батьків» виявив, що батьки, які у взаємодії 3 дітьми проявляють співчуття та емпатію, тим самим допомагають їм боротися із власними негативними почуттями, та сприяють кращому засвоєнню цінностей і зростанню духовно збагачених особистостей [Готтман, Деклер, 2018: с. 124].

Сучасний науковець у галузі психології В. Зарицька в своїх працях трактує поняття емоційного інтелекту як інструменту пізнання навколишнього середовища, соціальних взаємин, власного внутрішнього світу. Він розвивається одночасно 3 такими життєво необхідними психологічними поняттями як рефлексія, інтроспекція, емоційна компетентність, ідентифікація та самоаналіз [Зарищька, 2011: c. 92].

Л. Буркова вважає, що емоційний інтелект - це надзвичайно важливий прояв розумової діяльності індивіда, адже має подвійний функціонал. Він, з одного боку, допомагає взаємодіяти з внутрішнім світом та протидіяти власним конфліктам, з іншого, сприяє процесу соціалізації, адаптації в суспільстві, допомагає взаємодіяти 3 оточуючими завдяки ефективному спілкуванню та чіткому аналізу емоцій співрозмовника [Буркова, 2010: с. 260].

Отже, емоційний інтелект - це спосіб і форма поведінки та ставлення людини до самої себе й оточуючих. Це вміння точно визначати та аналізувати емоції, які виражають оточуючі, та передбачати їхні 


\section{Psychology}

наслідки. Тому кожній особистості важливо розуміти не лише свої відчуття, а й емоції інших людей, які часто пов'язані як з внутрішніми, так i 3 зовнішніми проявами поведінки. Емоційний інтелект і дорослого i дитини може розвиватися за допомогою живопису, мистецтва, літератури та гри.

Формулювання цілей статmі. Метою статі є здійснення теоретичного аналізу феномену емоційного інтелекту в контексті розвитку творчої уяви дошкільників, обгрунтування впливу дитячої літератури на розвиток емоційного інтелекту та творчого потенціалу, виявлення взаємозв’язку між емоційним інтелектом дітей дошкільного віку та їх здатністю до рефлексії.

Виклад основного матеріалу. Головним завданням дитячої літератури, яка сприяє розвиткові емоційного інтелекту та рефлексії в дошкільному віці, $є$ безперервне віддзеркалення навколишнього світу дитиною на основі розвитку іiі творчого потенціалу. Дитина в ранніх проявах розумової активності має бути забезпечена інформацією у довільній формі, наприклад, казками. Це допоможе їй розвивати асоціативне мислення, формувати аксіологічні орієнтири. У дошкільному віці дитина потребує постійного насичення новою інформацією, яка спочатку слугуватиме своєрідною основою світосприйняття, а в подальшому вже сприятиме розвитку творчої уяви.

Також варто відзначити, що розвиток творчої уяви неможливий без удосконалення чуттєво-образного мислення, що є невід'ємною складовою у формуванні творчого потенціалу дитини. Інформативне накопичення дає можливість дитині в подальшому легше справлятися із внутрішньоособистісними конфліктами та майбутньою кризою, яка пов’язана 3 початком відвідування дитиною школи.

Процес розвитку емоційного інтелекту має свої особливості, проте основні його структурні елементи починають розвиватися в старшому дошкільному віці та вдосконалюються впродовж усього шкільного періоду навчання. Уже в старших класах дитина-підліток має можливість досягти такого високого рівня розвитку емоційного інтелекту, щоб у дорослому житті успішно продовжувати навчання, налагоджувати комунікації з мало знайомими людьми в нових соціальних умовах.

Здатність дитини виокремити себе у світі починається з моменту іiі інтеграції в соціум. Становлення власного «я» дитини дошкільного віку цілком залежить від впливу культурних надбань середовища, в якому вона зростає. Від нього залежить не лише успішність, а й темп процесу соціалізації. Ще 3 раннього дитинства дорослі починають знайомити дитину зі світом казкових героїв. Бо саме казка через свою доступність для розуміння дає можливість дитині позиціонувати себе частиною суспільства, прищеплює аксіологічні орієнтири, пояснює співставлення позицій «добра» та «зла». Варто відзначити вплив цього різновиду творчості як форми психоемоційного орієнтиру індивіда, який дозволяє 
дитині розрізняти як позитивні, так і негативні прояви та вчинки на прикладі казкових героїв.

Казкотерапія - це такий напрям практичної психології, який, використовуючи метафоричні ресурси казки, дозволяє людям розвивати самосвідомість і розбудовувати особливу взаємодію один 3 одним для подальшого насиченого життя [Музичук, 2012: c. 317].

Казкотерапія - це відносно новий напрямок, проте один 3 найдієвіших способів психологічної допомоги та підтримки, адже перші історії з'явилися одночасно з появою мови. Створювалися оповідання та розповіді, які переповідалися людьми з метою передачі та засвоєння знань, досвіду, прикладів взаємодії людини та природи. Досвід людства, приклади почуттів, дій героїв, варіанти взаємодії із зовнішнім світом - все це було і $є$ онтогенезом слова та мови, за допомогою яких суспільством було створено казку як засіб терапії. Казкотерапія також є і системою виховання, яка дозволяє дидактично формувати уявлення про базові життєві цінності.

Варто також проаналізувати глибинний зв'язок казки та людського підсвідомого. Оповідання та розповіді, що використовуються в казкотерапії, насичені символами, образами та метафорами, які в свою чергу спонукають слухача до асоціацій. Це одна з функцій казкотерапії, яка дає змогу усвідомити, що свідомість витіснила у підсвідоме і від чого відмовилась, тобто, розвивається їі самосвідомість. Поступово все набуває ознак контрольованості та природно інтегрується в реальний досвід людини, отже відбувається процес саморегуляції. В оповіданнях на прикладах дій героїв набувається власний досвід, який інтегрується у свідомість людини та в подальшому сприятиме розвитку соціальної чутливості, здатності до врегулювання стосунків, напрацювання нових способів взаємодії з самим собою та оточуючим світом. Тому важко переоцінити їі значущість у вихованні дошкільників.

Основним ключовим функціоналом казки $є$ відтворення асоціативного процесу та удосконалення творчої уяви, що виникає через аналіз індивідом взаємодії головних персонажів та казкового світу (чуттєво-образне сприйняття дитиною оповідання). У процесі розглядання ілюстрацій розвивається асоціативне мислення, здатність до порівняння. Співставляючи себе 3 головним героєм, дитина здатна програмувати себе на несвідомому рівні в плані позитивних чи негативних поведінкових настанов. Інакше кажучи, вона бере приклад, наслідує вчинки, вчиться розпізнавати моральність та аморальність. Цей процес доволі складний, але уособлює в собі перші кроки до інтелектуального вдосконалення індивіда.

Спроможність ототожнювати себе з героями казки дає змогу дитині ще в ранні роки асоціювати добро 3 хорошими вчинками, а зло - iз лиходійством, несправедливістю, жорстокістю. Тобто, за допомогою казок вона змалечку намагається зрозуміти такі моральні максимуми суспільства, як відповідальність, шляхетність та великодушність. Тому дошкільники в 


\section{Psychology}

реальному житті через гру намагаються відтворювати поведінку героїв казок.

Повертаючись до аналізу функціоналу казки та виокремлення основного впливу художньої літератури на дітей, доцільно зазначити, що такий вид творчості дає змогу дитині за допомогою власної уваги та уяви аналізувати й порівнювати вчинки героїв оповідання, встановлювати причинно-наслідкові зв'язки дій персонажів, вчитися робити власні висновки. Такий вид інтелектуального навантаження здатен розвивати механізми самосвідомості та ідентифікації. Якщо з процесом ідентифікації дитина справляється достатньо швидко, то задатки рефлексії виникають тільки у дошкільному віці. Саме тому варто приділяти казкам та художній літературі більше часу, це свого роду інвестиція в майбутнє індивіда.

На думку Я. Пономарьова, рефлексія $\epsilon$ однією 3 головних характеристик творчості, коли людина стає для самої себе об'єктом управління. Рефлексія подібна дзеркалу, яке відображає всі особистісні зміни. У даному контексті рефлексія є основним засобом саморозвитку, умовою i способом трансформації розумових здібностей [Пономарёв, 1999: с. 144].

Свого часу класик Л. Виготський відмічав, що дитина не достатньою мірою усвідомлює власні розумові операції і тому не здатна в повному обсязі оволодіти ними. Вона ще неспроможна повною мірою до глибинного аналізу та інтроспекції. Тільки під впливом дискусій, протиріч та заперечень дитина намагається відшукати інші, більш складні шляхи для перетворення інформації [Выготский, 2005: с. 605].

В. Давидов поняття рефлексії пояснював як уміння суб'єкта «виділяти, аналізувати і співвідносити з предметною ситуацією власні дії». У цьому випадку рефлексія розглядається у своєму інтелектуальному аспекті [Давыдов, 2000: с. 176]. Загалом дослідником було виокремлено чотири основні види цього психологічного феномену: кооперативний, комунікативний, особистісний, інтелектуальний.

Важливим у всіх наведених вище поняттях $\epsilon$ те, що вони у своїй сукупності визначають різноманіття змістів, що виступають як предмети, на які може бути спрямована рефлексія. Це явище якнайкраще спостерігаємо на прикладі дитячої літератури:

-казки розвивають здатність дитини формулювати певні переконання про внутрішній світ персонажів казки, пояснюють причини їхніх вчинків - у цьому полягає комунікативна рефлексія;

-художня література дозволяє на прикладі взаємодії персонажів аналізувати систему стосунків - кооперативна рефлексія;

-властивості, якості, поведінкові характеристики, статус персонажа казки відносимо до особистісної рефлексії;

-ще однією функцією дитячих оповідань є розвиток інтелектуальних можливостей індивіда, які виявляються у процесі розв'язання різних задач та умінні аналізувати. 
Опрацювання дошкільником художніх оповідань сприяє покращенню мозкової активності. Пізнаючи світ книг, дитина починає ознайомлюватися 3 нормами суспільства, стає більш мобільною у прийнятті соціально відповідальних рішень, отже, має всі шанси на проходження процесу соціалізації більш динамічно. Варто зазначити, що вплив казок на дитину має досить абстрактний характер, проте цей вплив доволі помітний. Адже, ще змалечку дитина, яка намагалася знаходити відповіді на власні запитання в художній літературі, у більш зрілому віці легше справляється із завданнями дорослого життя. Творчий підхід у розв'язанні завдань, до яких дитина звикла змалечку, сприятиме i в подальшому більш доцільно використовувати та розвивати свій власний творчий потенціал. У більшості випадків рушійною силою та джерелом розвитку особистості $€$ iі творчий потенціал. Ця проблема знайшла своє відображення в працях таких учених, як А. Матюшкін, М. Муканов, Я. Пономарьов, С. Степанов, Є. Варламова та ін. Вони розкривають саме поняття творчого потенціалу особистості, розглядаючи його на рівні вивчення потенційних і актуальних характеристик людини. Основна ідея в працях учених полягає в тому, що творчий потенціал інтерпретується як форма творчої активності особистості. Творчий потенціал - це динамічна структура, яка включає комплекс творчих задатків, що проявляються у творчій активності особистості та обумовлена креативністю.

Творча активність у загальному масштабі культури приводить до унікальності людини в культурно-історичному аспекті та іiі феноменальності. Тобто, сама людина є явищем феномену культури, і в результаті цього іiі творчість стає важливою в широкому соціальному просторі. Творча унікальність такої людини є і умовою, i результатом творчого процесу. Крім того, за такої умови спостерігається можливість усвідомленого вибору людиною творчої життєвої позиції та розвитку свого творчого потенціалу [Варламова, Степанов, 2002: с. 201].

Аналізуючи праці вищезазначених науковців, припускаємо, що творчі здібності тісно пов'язані з інтелектом. Теорію підсилює концепція десяти тисяч годин праці М. Гладуелла. Відомий сучасний американський соціолог у своїй книзі «Генії та аутсайдери» описує феномен успішних людей, які стали віртуозами у своїй справі завдяки постійним удосконаленням, наполегливій праці та самоаналізу. Автор підкреслює значущість системної роботи як запоруку професіоналізму та геніальності, наводячи приклад таких знаменитих людей, як Б. Гейтс, Б. Джой, Р. Опенгеймер, В. Моцарт, П. Макартні.

Припущення полягає в тому, що для досягнення успіху в будь-якій сфері життя та для досягнення високого рівня майстерності зі статусом експерта світового класу, потрібно близько ста тисяч годин практики. I ця умова стосується всіх професій без винятку. Десять тисяч годин - це приблизно три години роботи в день, або двадцять годин на тиждень протягом десяти років. Це не пояснює, чому деяким людям заняття 


\section{Psychology}

корисніші, ніж іншим, але поки що не відомий випадок, коли найвищий рівень майстерності був би досягнутий за менший час. Складається враження, що рівно стільки часу потрібно мозку, щоб засвоїти всю необхідну інформацію.

Ідея М. Гладуелла полягає у пристосуванні людини до систематичного розумового навантаження, яке згодом дає їй змогу бути більш успішною в обраному професійному напрямі діяльності [Гладуэлл, 2009: c. 25].

Дитина, яка змалечку привчена сприймати і переробляти відносно великий обсяг інформації, в подальшому розширює ці межі аж до створення власного творчого продукту уяви. Американський дослідник вважає під поняттям геніальності не вроджений дар, а успіх, який зумовлений тяжкою працею, удосконаленням, постійними інтелектуальними збагаченнями. Варто відзначити це як основну умову успішності. Якщо розумова активність індивіда ще 3 дошкільного віку матиме систематичний прогресивний характер, то вона й у дорослому віці матиме низку переваг, зокрема, конкурентоспроможність, яку суттєво помітно в оточенні однолітків.

Тому, якщо 3 раннього віку розвивати у дитини увагу, уяву, пам'ять, мислення, то й надалі вона буде придатна і до більш ємкої інтелектуальної праці. Першоосновою цих здатностей індивіда $\epsilon$ осмислення ним соціальних процесів, причинно-наслідкових зв'язків та норм поведінки, що закладені у спростованій формі казкового світу.

Висновки. Отже, можемо зробити висновок, що на сучасному етапі розвитку суспільства, в період стрімкого розвитку інформаційних технологій надважливим $\epsilon$ розвиток особистісного потенціалу, самовдосконалення та робота над собою. На поприщі психологічної науки відомим $\epsilon$ той факт, що найбільш ефективним $є$ індивідуальний розвиток інтелектуального потенціалу саме дітей дошкільного віку, адже, наполеглива розумова активність дітей обов'язково стане в нагоді в процесі соціалізації. Сучасна наука намагається більш ретельно дослідити розумову діяльність на ранніх етапах становлення окремих властивостей інтелекту. Завдяки плідним зусиллям учених розуміємо взаємозалежність успішності особистості та емоційного інтелекту, творчого потенціалу, рефлексії та інтроспекції.

Чим раніше дитина починає усвідомлювати себе, відчувати власний неповторний внутрішній світ, працювати над помилками, розвивати іманентний (внутрішній) моральний стержень, тим легше відбувається процес соціалізації та успішна адаптація в суспільстві. Творча уява $\epsilon$ центральним елементом у складному переліку психологічних інструментів пізнання дитиною світу, яка розвивається у синергії з рефлексією та інтроспекцією.

Захоплення дитиною казками може відіграти ключову роль у самостійності прийнятих нею соціально відповідальних рішень, адже казка 
з її моральним центральним посилом зміцнює морально-етичні настанови індивіда. Завдяки розвитку рефлексії та інтроспекції дитина вчиться аналізувати проблеми казкового світу на теоретичному рівні, переносити ці знання в реальність та застосовувати їх на практиці, адже безліч казок мають виховний, навчальний та пізнавальний характер, часто демонструють приклади соціально бажаної поведінки, наприклад, ознайомлення з етичним нормами. За схожим алгоритмом, за допомогою оповідань, розвивається і здатність до рефлексії - уміння прорахувати власну соціально-небажану поведінку і наслідки хибних рішень.

Натомість, під емоційним інтелектом розуміємо більш повне поняття, яке містить не лише самовідчуття, а й розуміння емоцій та почуттів співрозмовника. Здатність швидко та вправно зчитувати настрій оточуючих допомагає дитині у процесі розв'язання різноманітних життєвих ситуацій, налагодженні соціально-важливих контактів.

\section{ЛITEPАТУРА}

Буркова, 2010 - Буркова Л. В. Соціономічні професії: інноваційна підготовка спеціалістів у вищих навчальних закладах: монографія. Київ : Інформаційні системи, 2010. 278 с.

Варламова, Степанов, 2002 - Варламова Е. П., Степанов С. Ю. Психология творческой уникальности. Москва : Институт психологии РАН, 2002. 256 с.

Выготский, 2005 - Выготский Л. С. Психология развития человека. Москва : Смысл; Эксмо, 2005. $1136 \mathrm{c}$.

Гладуэлл, 2010 - Гладуэлл М. Гении и аутсайдеры: Почему одним все, а другим ничего? / пер. с англ. 2-е изд. Москва : ООО Юнайтед Пресс. 2010. 256 с.

Готтман, Деклер, 2018 - Готтман Дж., Деклер Дж. Эмоциональный интеллект ребенка. Практическое руководство для родителей. Москва : ООО Манн, Иванов и Фербер. 2018. $288 \mathrm{c}$.

Давыдов, 2000 - Давыдов В. В. Виды обобщения в обучении: Логико-психологические проблемы построения учебных предметов. Москва : Педагогическое общество России, 2000. $480 \mathrm{c}$.

Зарицька, 2011 - Зарицька В. В. Розвиток емоційного інтелекту в контексті компетентнісно спрямованої освіти. Компетентнісно спрямована освіта: перший досвід, порівняльні niдxоди, перспективи: зб. матеріалів доп. учасн. Всеукр. наук.-практ. конф. Київ, 2011. C. 92.

Музичук, 2012 - Музичук О. О. Казка як засіб розвитку особистісних цінностей молодших школярів. Проблеми сучасної психології : зб.наук. праць. Камянець-Подільський : Аксіома, 2012. Вип. 17. С. 317-327.

Пономарёв, 1999 - Пономарёв Я. А. Психология творения: избранные психологические труды. Воронеж : НПО Модэк. 1999. $480 \mathrm{c}$.

Савченко, 2015 - Савченко Ю. Ю. Розвиток емоційного інтелекту учнів молодшого шкільного віку. Освіта та розвиток обдарованої особистості. 2014. Вип. № 12 (31) С. 12-16 URL: http://nbuv.gov.ua/UJRN/Otros_2014_12_5 (дата звернення: 8.07.2019).

\section{REFERENCES}

Burkova, 2010 - Burkova L. V. Sotsionomichni profesii: innovatsiyna pidhotovka spetsialistiv u vyshchykh navchalnykh zakladakh: monohrafiia. Kyiv : Informatsiini systemy, 2010. $278 \mathrm{~s}$.

Varlamova, Stepanov, 2002 - Varlamova E. P., Stepanov S. Yu. Psykhologiia tvorcheskoy unykalnosty. Moskva : Ynstitut psykhologii RAN, 2002.256 s.

Vygotskyi, 2005 - Vygotskiy L. S. Psikhologiia razvitiia cheloveka. Moskva: Smisl; Eksmo, 2005. $1136 \mathrm{~s}$. 


\title{
Psychology
}

Gladuell, 2010 - Gladuell M. Genii i autsaidery: Pochemu odnim vse, a drugim nychego? / per. s angl. 2-e izd. Moskva : OOO Yunaited Press. 2010. 256 s.

Gottman, Dekler, 2018 - Gottman Dzh., Dekler Dzh. Emotsionalnyy intellekt rebenka. Prakticheskoe rukovodstvo dlia roditeley. Moskva : OOO Mann, Ivanov i Ferber, 2018. $288 \mathrm{~s}$.

Davydov, 2000 - Davydov V. V. Vidy obobshcheniia v obuchenii: Logiko-psykhologicheskie problemy postroeniia uchebnykh predmetov. Moskva : Pedagogicheskoe obshchestvo Rossii, 2000. $480 \mathrm{~s}$.

Zarytska, 2011 - Zarytska V. V. Rozvytok emotsiinoho intelektu v konteksti kompetentnisno spriamovanoi osvity. Kompetentnisno spriamovana osvita: pershyi dosvid, porivnialni pidkhody, perspektyvy: zb. Materialiv dop. uchasn. Vseukr. nauk.-prakt. konf. Kyyiv, 2011. S. 92.

Muzychuk, 2012 - Muzychuk O. O. Kazka iak zasib rozvytku osobystisnykh tsinnostei molodshykh shkoliariv. Problemy suchasnoyi psykholohiyi: zb. nauk. prats. Kamianets-Podilskyi. Aksioma, 2012. Vyp. 17. S. 317-327.

Ponomarev, 1999 - Ponomarev Ya. A. Psykhologiia tvoreniia: izbrannye psykhologicheskye trudy. Voronezh : NPO Modek. 1999. $480 \mathrm{~s}$.

Savchenko, 2015 - Savchenko Yu. Yu. Rozvytok emotsiinoho intelektu uchniv molodshoho shkilnoho viku. Osvita ta rozvytok obdarovanoyi osobystosti. 2014. Vyp. № 12 (31) S. 12-16. URL: http://nbuv.gov.ua/UJRN/Otros_2014_12_5 (data zvernennia: 8.07.2019).

\author{
Галина Радчук, \\ доктор психологічних наук, \\ професор, завідувач кафедри \\ практичної психології \\ Тернопільського національного \\ університету \\ імені Володимира Гнатюка
}

\author{
Halyna Radchuk, \\ Doctor of Psychological Sciences, \\ Professor, \\ Head of the Department \\ of Practical Psychology \\ of Volodymyr Hnatiuk Ternopil \\ National University
}

\section{КУЛЬТУРНО-ПСИХОЛОГІЧНИЙ ПІДХІД У КОНТЕКСТІ СІМЕЙНОГО ВИХОВАННЯ}

\begin{abstract}
У статті проаналізовано концептуальні засади культурно-психологічного підходу в сімейному вихованні. Виокремлено три основних підходи до визначення культури: иіннісний (аксіологічний), діяльнісний та особистісний. Визначено, щяо культурний розвиток досить часто розглядається з точки зору розвитку діяльності, щзо приводить до редукування иілісного становлення особистості дитини, до розвитку виключно інтелектуальних структур. Зауважено, що в поясненні місия людини в культурі як $і$ раніше використовується об'єктний підхід, у відповідності з яким культура надбудовується над людиною, а не проявляється у ї̈ власному бутті та життєтворчості. Доведено, щзо культура - ие середовище, яке вирощує $i$ живить розвиток особистості, а культурно-психологічний підхід у сфері сімейного виховання передбачає розвиток дитини як особистості, індивідуальності й активного суб 'єкта діяльності та може бути реалізований лише на основі побудови діалогічної стратегї діяльності дорослого. Обірунтовано освітній діалог, як культурно доиільну форму навчання, спрямовану на перетворення внутрішнього, духовного досвіду батьків і майбутніх батьків та набуття нового в ияарині сімейного виховання, а також розвитку діалогу як необхідної умови розгортання особистісного потенціалу дитини у сім'ї. Розроблено освітню програму, в якій діалог виконує двоєдине завдання: 1) як умова становлення повноцінної особистості дитини в сім' $\dddot{i}$; 2) як ефективна форма навчання батьків інноваційним підходам у сфері сімейного виховання. Визначено методичні особливості
\end{abstract}

